\title{
HPLC Method for Determination of the Chemical Stability of Antimicrobial Peptide $\alpha$-Defensin 2
}

\author{
Vania Maslarska ${ }^{1, *}$, Meri Amerikova ${ }^{2}$, Ivanka Pencheva ${ }^{2}$, Stanislav Bozhanov ${ }^{1}$ \\ ${ }^{1}$ Department of Chemistry, Faculty of Pharmacy, Medical University-Sofia, 2 Dunav St., 1000 Sofia, BULGARIA. \\ ${ }^{2}$ Department of Pharmaceutical Chemistry, Faculty of Pharmacy, Medical University-Sofia, 2 Dunav St., 1000 Sofia, BULGARIA.
}

\begin{abstract}
Aim: The aim of this research study was to develop a simple, rapid, precise, accurate and economical RP-HPLC method, with a simple mobile phase for the identification and determination of the antimicrobial peptide $\alpha$-defensin-2. Materials and Methods: Separation was carried out at $25^{\circ} \mathrm{C}$, using column Luna $5 \mathrm{U}\left(\mathrm{C}_{18}, 250 \times 4.6,5 \mu \mathrm{m}\right)$ with mobile phase consisting of acetonitrile: water (40: $60 \mathrm{v} / \mathrm{v})$. The detector was set at 210 $\mathrm{nm}$. The flow rate was $1.2 \mathrm{ml} / \mathrm{min}$ and injection volume was $20 \mu \mathrm{l}$. Results: The developed method was validated as per ICH guidelines and the kinetic behavior of $\alpha$-defensin 2 was studied in respect of different $\mathrm{pH}$. Conclusion: The obtained data can serve for creating an in vivo monitoring program and quality control for different studies and preparations.
\end{abstract}

Key words: Antimicrobial peptides, $\alpha$-defensin 2, HPLC, Chemical stability, Analysis.

\section{INTRODUCTION}

Antimicrobial peptides are one of the earliest molecular effects of innate immunity. They occur in different species. ${ }^{1}$ In animal and plant kingdoms, multiple families of molecules have similar modes of action against a wide range of bacteria, fungi and enveloped viruses. These families have several general properties, including broad-spectrum antimicrobial activity and positive charge at physiological $\mathrm{pH}$. The activity of most antimicrobial peptides is a direct result of electrostatic binding with anionic moieties on the microbial membrane and subsequent destruction of the membrane, although other mechanisms are proposed. ${ }^{2}$ The most widely studied family of antimicrobial peptides are defensins. There are over 80 different $\alpha-, \beta$ - and $\theta$-defensins spanning numerous phyla. ${ }^{3-5}$ Humans possess at least six $\alpha$-defensins and two $\beta$-defensins, as well as many other antimicrobial peptides. According to Ganz et al. the $\alpha$ or classical defensins are $\beta$-sheet structured that possess in vitro microbicidal activity $^{6}$ at micromolar concentrations against Gram-positive and Gram-nega- tive bacteria, fungi, yeast and enveloped viruses. ${ }^{7-10}$ Four human $\alpha$-defensins occur: human neutrophil peptides (HNP-1, -2, -3 and -4), which are stored in the granules of neutrophils 3 . Two other $\alpha$-defensins, namely human $\alpha$-defensins 5 and 6 (HD- 5 and- 6 , are found in the Paneth cell granules. ${ }^{11-13}$ All $\alpha$-defensins contain six cysteine amino acid residues, linked in three disulfide bonds. $\alpha$-defensins have the ability to interact with microbial cell wall components, most often membrane lipids, leading to damage of biological membranes. The total cellular protein content of neutrophils includes about $5-7 \%$ of HNPs and the same time HNPs represent around $35-50 \%$ in azurophil granules. ${ }^{14-16}$ The clinical relevance of HNPs 1-3 has been studied relatively extensively, from the other hand, less is known about other $\alpha$-defensins. ${ }^{14,17}$ Studies show that various diseases can be associated with elevated concentrations of HNPs 1-3 in different body fluids. ${ }^{15,18,19}$

For example, increased concentrations of HNPs 1-3 were found in patients with
Submission Date: 23-08-2019; Revision Date: 14-12-2019; Accepted Date: 08-01-2019

DOI: 10.5530/ijper.54.2.53 Correspondence: Vania Maslarska,

Department of Chemistry, Faculty of Pharmacy, Medical University-Sofia, 2 Dunav st., 1000 Sofia, BULGARIA.

Phone: +359-02-9236522

E-mail:vmaslarska@mail.bg

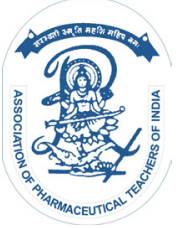

www.ijper.org 
pulmonary diseases; ${ }^{15,20-24}$ gastrointestinal diseases like ulcerative colitis, Crohn's disease and gastric or colorectal cancer; ${ }^{25-31}$ renal cell carcinoma ${ }^{32,33}$ and oral diseases. $^{34-36}$

To explore the role of HNP-1, -2 and -3 as diagnostic markers for specific diseases, a widely applicable analytical assay would be beneficial.

In the literature use of LC with UV detection for the quantification of HNP-1 in saliva is reported. ${ }^{34-36}$ Quantitative assay for HNP-1, -2 and -3 in saliva samples using LC-MS also has been reported. ${ }^{37}$

Literature survey reveals that no RP-HPLC analytical method has been reported yet for the determination of antimicrobial peptide $\alpha$-defensin-2. That is why the aim of this research study was to develop a simple, rapid, precise, accurate and economical RP-HPLC method for assay and chemical stability of antimicrobial peptide $\alpha$-defensin-2. The method was validated in accordance with ICH (ICH Q2, 2005) guidelines. ${ }^{38}$

\section{MATERIALS AND METHODS}

\section{Reagents and Chemicals}

Acetonitrile HPLC grade, deionized water (DI), buffers with $\mathrm{pH}=2,4,7.4$ and $9 \mathrm{pH}$ units prepared according European Pharmacopoeia 8.0, lyophilized amorphous powder of Human Neutrophil Peptide-2 $\alpha$-defensin 2 (M.W. 3371.0, $\mathrm{C}_{147} \mathrm{H}_{217} \mathrm{~N}_{43} \mathrm{O}_{37} \mathrm{~S}$ ), Peptide institute, Japan, provided by Pepta Nova GmBH.

\section{Apparatus and analytical conditions}

A high-performance liquid chromatographic system (SHIMADZU Corporation, LC-20 AD) with an auto sampler, Shimadzu DGU-20A5 vacuum degasser and a Shimadzu SPD-20A, UV/VIS detector were used for analysis. Separation was carried out at $25^{\circ} \mathrm{C}$, using column Luna $5 \mathrm{U}\left(\mathrm{C}_{18}, 250 \times 4.6,5 \mu \mathrm{m}\right)$ with mobile phase, prepared by mixing filtered and degassed acetonitrile: water - 40: $60 \mathrm{v} / \mathrm{v}$. The detector was set at $210 \mathrm{~nm}$. The flow rate was $1.2 \mathrm{ml} / \mathrm{min}$ and the run time was $10 \mathrm{~min}$. Before analysis both the mobile phase and sample solutions were degassed by the use of a sonicator and filtered through a $0.45 \mu \mathrm{m}$ filter and injection volume was $20 \mu \mathrm{l}$. The chromatogram is shown in Figure 1.

\section{Preparation of Stock Solution}

Solution (a) of $\alpha$-defensin 2 was prepared by dissolving of $0.0012 \mathrm{~g}$ from lyophilized amorphous powder with DI water to obtain solution with concentration $0.0024 \mathrm{~g} / \mathrm{ml}$.

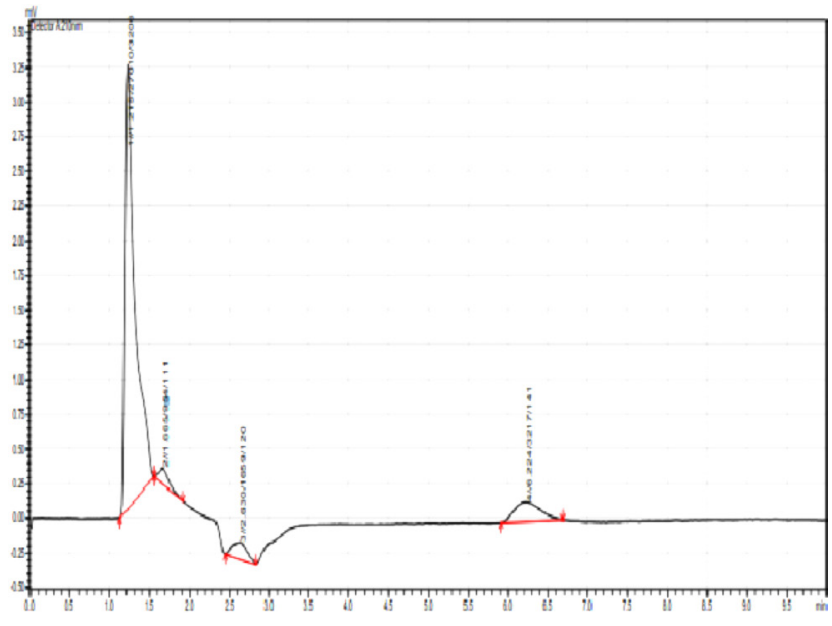

Figure 1: Chromatogram of $\alpha$-defensin $2(\operatorname{tr}=1.215 \mathrm{~min})$ in solvent DI-water.

\section{Preparation of Test Solutions}

Solutions (b) of $\alpha$-defensin 2 were prepared by dissolving of 50, 100 and $150 \mu \mathrm{l}$ aliquots from solution (a) in DI water to obtain solutions with concentration 0.00012 , 0.00024 and $0.00036 \mathrm{~g} / \mathrm{ml}$.

\section{Preparation of Samples for Chemical Stability Studies}

Sample solutions (c) of $\alpha$-defensin 2 were prepared by dissolving of $200 \mu \mathrm{l}$ aliquots from solution (a) in 900 $\mu$ l buffer solution with $\mathrm{pH}=2,4,7.4$ or $9 \mathrm{pH}$ units. The obtained test solutions were heated at temperature $37^{\circ} \mathrm{C}$ at continuously stirring. After that $200 \mu \mathrm{l}$ of the samples were taken, diluted to $4000.0 \mu \mathrm{l}$ with the mobile phase. An aliquot sample of $20 \mu \mathrm{l}$ of the analyzed solutions were taken at definite time intervals $(0,30,60,90,120,150,180,240 \mathrm{~min})$ and were injected.

\section{Method Validation}

The proposed method was validated under the established optimal chromatographic conditions. The validation as per ICH guidelines ${ }^{38}$ was carried out with respect to specificity, linearity, repeatability, accuracy, system suitability and sensitivity (Limit of Quantitation (LOQ) and Limit of Detection (LOD)).

\section{Specificity}

The specificity of the HPLC method was established by analyzing standard $\alpha$-defensin 2 solution. The retention time of $\alpha$-defensin 2 was confirmed by comparing its retention time with that of the standard (Figure 1).

\section{Linearity}

From the stock solution (a) were prepared working solutions within the concentration range $25 \%$ to $200 \%(0.06 ; 0.12$; $0.24 ; 0.36 ; 0.48 \mathrm{mg} / \mathrm{ml})$. Each solution was injected in triplicate. 
Table 1: Results from repeatability study of $\alpha$-defensin 2.

\begin{tabular}{|c|c|c|c|c|}
\hline $\mathbf{N}$ & $\mathbf{t}_{\mathbf{R}}, \mathbf{m i n}$ & Area, A & $\begin{array}{c}\text { High, } \mathbf{h} \\
(\mathbf{A U})\end{array}$ & Amount, \% \\
\hline 1. & 1.208 & 28355 & 2889 & 60.459 \\
\hline 2. & 1.210 & 21913 & 2417 & 79.379 \\
\hline 3. & 1.215 & 27010 & 3206 & 82.250 \\
\hline 4. & 1.209 & 30759 & 3283 & 71.902 \\
\hline 5. & 1.215 & 23695 & 2545 & 66.969 \\
\hline $\mathrm{X}_{\text {mean }}$ & 26346.4 & & & \\
\hline $\mathrm{SD}$ & \pm 3182.16 & & & \\
\hline $\mathrm{RSD}$ & $12.06 \%$ & & & \\
\hline
\end{tabular}

The plotting mean chromatographic peak area against the concentration of each solution was made.

\section{Repeatability}

Solution (b) with concentration $0.00024 \mathrm{~g} / \mathrm{ml}$ was analyzed five times by the proposed method (Table 1).

\section{Accuracy (recovery method)}

The accuracy of HPLC method was tested by calculating the recovery of three solutions containing $\alpha$-defensin 2 in concentration ratio $50-150 \%$ of theoretically calculated quantity (concentrations are as follows - 0.00012, 0.00024 and $0.00036 \mathrm{~g} / \mathrm{ml})$.

\section{Limiting values}

The Limit of Detection (LOD) was considered the lowest concentration of the analytes corresponding to three times the background noise or relationship signalto-noise ratio 3:1.

The Limit of Quantification (LOQ) was defined as the lowest point of the calibration curve and fulfilled the requirement of LOQ signal-to-noise ratio of 10:1. ${ }^{37,38}$

\section{RESULTS AND DISCUSSION}

\section{Selection of Mobile phase}

Different combinations of acetonitrile and water were tested and the optimum condition at acetonitrile-water (40:60 v/v) was reached.

\section{Selection of flow rate and column temperature}

The temperature of the column was varied between $25^{\circ} \mathrm{C}$ and $40^{\circ} \mathrm{C}$, in an attempt to reduce the overall run time as well as to improve peak shape and sensitivity. However, due to negligible differences in method performance, the column temperature was set up at $25^{\circ} \mathrm{C}$. Also, increasing the flow rate from $1 \mathrm{ml} / \mathrm{min}$ to $1.5 \mathrm{ml} / \mathrm{min}$ showed a similar effect on the retention time. The optimum flow rate was $1.2 \mathrm{ml} / \mathrm{min}$. The obtained chromatogram is shown in Figure 1. The proposed chromatographic conditions indicate that the method is selective and could be applied for simultaneous identification and quantification of the $\alpha$-defensin 2.

\section{Validation of HPLC method for studying chemical stability of $\alpha$ defensin 2}

\section{Specificity}

Specificity in respect of reagents - "Blank" solution without $\alpha$-defensin 2 was prepared. There were no peaks in the chromatogram obtained from this solution with retention time $\left(t_{R}\right)$ of $\alpha$-defensin 2 .

\section{Linearity}

The linear calibration curve for $\alpha$-defensin 2 was constructed with five concentration levels each under the experimental conditions described above. The calibration curve of $\alpha$-defensin 2 was subject to regression analysis to calculate the regression equation and the correlation coefficient. The analytical parameter linearity was studied in concentration range $0.06-0.48 \mathrm{mg} / \mathrm{ml}$. The correlation coefficient $\left(R^{2}\right)$ was found to be 0.970 . Slope is $1.2648 \mathrm{E} 9$ at standard error $1.10127 \mathrm{E} 8$ and intercept is 4768.7409 at standard error 1619.6069.

\section{Repeatability}

The results for repeatability were presented in Table 1. Standard deviation (SD) and relative SD (RSD) were found based on using area values in absorption units (AU).

\section{Accuracy /Recovery}

Accuracy of the proposed method was determined using recovery studies. The recovery study results of the $\alpha$-defensin 2 ranged from $96.5 \%$ to $103.1 \%$ using solution of sample preparation. The coefficients of variation for this technique were lower than $5 \%$.

\section{System suitability test}

For system suitability test determination of some chromatographic parameters such as retention time in different solvents (mobile phase and buffer solutions), relative retention toward secondary peaks, LOD and LOQ were appointed for optimization of conditions. The results are shown on Table 2 .

\section{Limit of Detection (LOD) and Limit of Quantitation (LOQ)}

The determined values of LOD and LOQ for the $\alpha$-defensin 2 in the proposed method are shown in Table 2. LOD was found to be $6 \mu \mathrm{g} / \mathrm{ml}$. and LOQ$12 \mu \mathrm{g} / \mathrm{ml}$. 


\begin{tabular}{|c|c|}
\hline \multicolumn{2}{|c|}{ Table 2: Results from System Suitability Test of $\alpha$-Defensin 2 in DI water and Buffer Solutions. } \\
\hline Parameters & Data $\alpha$-defensin 2 \\
\hline$t_{R}$ (retention time) + SD in DI water solution, min & $1.2+0.011$ \\
\hline Relative retention against largest secondary peak in DI water & 0.78 \\
\hline Relative retention against largest secondary peak in buffer solution with $p H=9$ & 0.73 \\
\hline Relative retention against largest secondary peak in buffer solution with $p H=2$ & 0.67 \\
\hline Tailing factor & 0.80 \\
\hline LOD (limit of detection), $\mu \mathrm{g} / \mathrm{ml}$ & 6 \\
\hline LOQ (limit of quantitation), $\mu \mathrm{g} / \mathrm{ml}$ & 12 \\
\hline
\end{tabular}

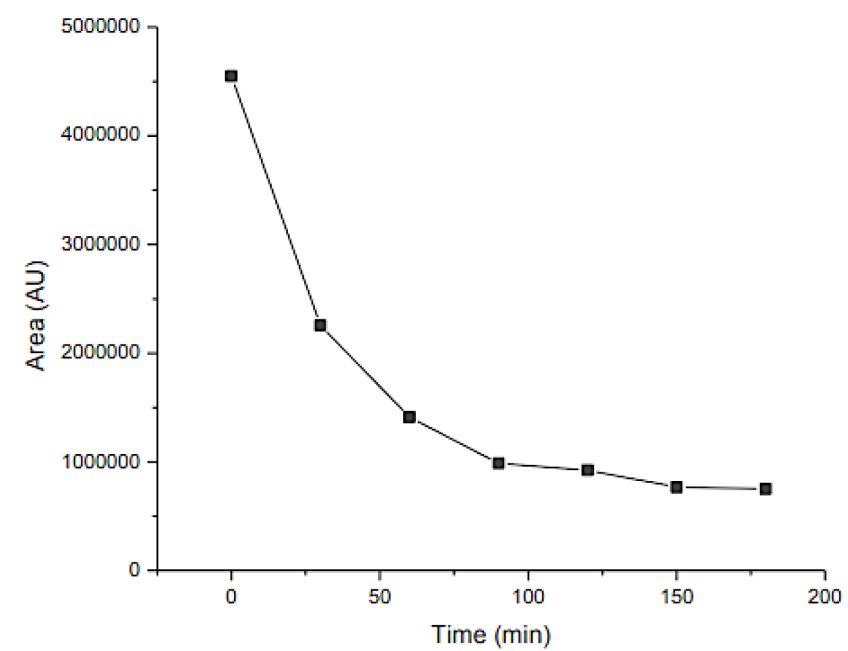

Figure 2: Kinetic profile of $\alpha$-defensin 2 in Buffer Solution with $\mathrm{pH}=9$.

\section{Chemical Stability of $\alpha$-defensin 2}

The chemical stability of $\alpha$-defensin 2 was studied by validated HPLC method at varied conditions: $\mathrm{pH}$ and time. The results are shown in Table 3. Stability data were based on chromatographic parameters $t_{r}$, area and height values at different $\mathrm{pH}$ in time intervals of $240 \mathrm{~min}$ for investigation in acid, neutral and alkaline media. The relative retention time of $\alpha$-defensin 2 and the second largest peak in solvent DI water and in alkaline and acid media is as follows: $0.78,0.73$ and 0.67 respectively and permits propriety in the purity tests.

Initially (about $30 \mathrm{~min}$ ) rapid hydrolysis of the substance was observed and then the process was slowed down during the experiment (240 min). The highest degree of degradation $\alpha$-defensin 2 shows in an alkaline medium $(\mathrm{pH}=9)$. The concentration of $\alpha$-defensin 2 is exponential function of the time. It is decreased gradually and the reaction we observed is the first-order reaction (Figure 2).

Different solvents - DI water, mobile phase, phosphate buffer with $\mathrm{pH}=4$, phosphate buffer with $\mathrm{pH}=7.4$ and buffers with $\mathrm{pH}=2$ and 9 affect the chemical stability of
Table 3: Results from HPLC assay of $\alpha$-defensin 2 in different solvents after $240 \mathrm{~min}$.

\begin{tabular}{|c|c|c|c|c|}
\hline Solvents & $\mathbf{t}_{\mathrm{R}}, \mathbf{m i n}$ & Area, A & Height, AU & Content, \% \\
\hline DI water & 1.165 & 2382 & 501 & 4.698 \\
\hline Mobile phase & 1.352 & 53199 & 2579 & 18.576 \\
\hline Buffer pH 2 & 1.353 & 682324 & 47777 & 40.826 \\
\hline Buffer pH 4 & 1.383 & 722960 & 32342 & 47.402 \\
\hline Buffer pH 7.4 & 1.468 & 1342810 & 64105 & 61.563 \\
\hline Buffer pH 9 & 1.525 & 4548095 & 254445 & 86.547 \\
\hline
\end{tabular}

$\alpha$-defensin 2 and the decomposed quantity varies from $4.698 \%$ in DI water to $86.547 \%$ in buffer with $\mathrm{pH}=9$ (Table 3).

\section{CONCLUSION}

A simple isocratic RP-HPLC method with UV detection has been developed for determination of $\alpha$-defensin 2 . The method was validated for accuracy, precision, specificity and linearity. The run time was relatively short (8 min). HPLC with UV detection becomes the most available apparatus and is a low-cost instrument in comparison with HPLC coupling with mass spectroscopy and capillary electrophoresis. The chemical stability profile of $\alpha$-defensin 2 was developed in acid, neutral and alkaline media with validated RP-HPLC method. The kinetic behavior of the peptide was appointed and presented as analytical model for monitoring. The obtained data can serve for creating an in vivo monitoring program and quality control for different studies and preparations.

\section{ACKNOWLEDGEMENT}

This study is a part of Grant project 47/2016 supported by Medicine Science Council, Medical University-Sofia.

\section{CONFLICT OF INTEREST}

Authors have no conflicts of interest to declare. 


\section{ABBREVIATIONS}

HPLC: High performance liquid chromatography; HNP: Human neutrophil peptides; HD: Human defensin; LC-MS: Liquid chromatography-mass spectrometry; ICH: International Conference on Harmonization; DI: Deionized water; LOQ: Limit of quantitation; LOD: Limit of detection; RSD: Relative standard deviation.

\section{REFERENCESS}

1. Boman HG. Peptide antibiotics and their role in innate immunity. Annu Rev Immunol. 1995;13(1):61-92.

2. Hancock RE, Chapple DS. Peptide antibiotics. Antimicrob Agents Chemother. 1992;43(6):1317-23.

3. Ganz T. Defensins and host defense. Science. 1999;286(5439):420-1.

4. Lehrer RI, Bevins CL, Ganz T. Defensins and other antimicrobial peptides. In: Editors Mucosal Immunology. San Diego: Academic Press. 1999;89-99.

5. Martin E, Ganz T, Lehrer RI. Defensins and other endogenous peptide antibiotics of vertebrates. J Leukoc Biol. 1995;58(2):128-36.

6. Ganz T, Selsted ME, Szklarek D, Harwig SS, Daher K, Bainton DF, et al. Defensins. Natural peptide antibiotics of human neutrophils. J Clin Invest. 1985;76(4):1427-35

7. Daher KA, Selsted ME, Lehrer RI. Direct inactivation of viruses by human granulocyte defensins. J Virol. 1986;60(3):1068-74.

8. Lehrer RI, Barton A, Daher KA, Harwig SS, Ganz T, Selsted ME. Interaction of human defensins with Escherichia coli. Mechanism of bactericidal activity. J Clin Invest. 1989;84(2):553-61.

9. Miyasaki KT, Bodeau AL, Ganz T, Selsted ME, Lehrer RI. In vitro sensitivity of oral, gram-negative, facultative bacteria to the bactericidal activity of human neutrophil defensins. Infect Immun. 1990;58(12):3934-40.

10. Ogata K, Linzer BA, Zuberi RI, Ganz T, Lehrer RI, Catanzaro A. Activity of defensins from human neutrophilic granulocytes against Mycobacterium avium-Mycobacterium intracellulare. Infect Immun. 1992;60(11):4720-25.

11. Jones DE, Bevins CL. Paneth cells of the human small intestine express an antimicrobial peptide gene. J Biol Chem. 1992;267(32):23216-25.

12. Jones DE, Bevins CL. Defensin 6 mRNA in human Paneth cells: Implications for antimicrobial peptides in host defense of the human bowel. FEBS Lett. 1993;315(12):187-92.

13. Szyk A, Wu Z, Tucker K, Yang D, Lu W, Lubkowski J. Crystal structures of human alpha-defensins HNP4, HD5 and HD6. Protein Sci. 2006;15(12):2749-60.

14. Ganz T, Lehrer RI. Antimicrobial peptides of leukocytes. Curr Opin Hematol. 1997;4(1):53-8.

15. Ihi T, Nakazato M, Mukae H, Matsukura S. Elevated concentrations of human neutrophil peptides in plasma, blood and body fluids from patients with infections. Clin Infect Dis. 1997;25(5):1134-40.

16. Lehrer RI, Ganz T, Selsted ME. Defensins: Endogenous antibiotic peptides of animal cells. Cell. 1991;64(2):229-30.

17. Wu Z, Ericksen B, Tucker K, Lubkowski J, Lu W. Synthesis and characterization of human alpha-defensins 4-6. J Pept Res. 2004;64(3):118-25.

18. Shiomi K, Nakazato M, Ihi T, Kangawa K, Matsuo H, Matsukura S. Establishment of radioimmunoassay for human neutrophil peptides and their increases in plasma and neutrophil in infection. Biochem Biophys Res Commun. 1993;195(3):1336-44.

19. Panyutich AV, Panyutich EA, Krapivin VA, Baturevich EA, Ganz T. Plasma defensin concentrations are elevated in patients with septicemia or bacterial meningitis. J Lab Clin Med. 1993;122(2):202-7.
20. Mukae $\mathrm{H}$, liboshi $\mathrm{H}$, Nakazato M, Hiratsuka T, Tokojima M, Abe K, et al. Raised plasma concentrations of alpha-defensins in patients with idiopathic pulmonary fibrosis. Thorax. 2002;57(7):623-8.

21. Mukae $\mathrm{H}$, Ishimoto $\mathrm{H}$, Yanagi $\mathrm{S}$, Ishii $\mathrm{H}$, Nakayama $\mathrm{S}$, Ashitani $\mathrm{J}$, et al. Elevated BALF concentrations of alpha-and beta-defensins in patients with pulmonary alveolar proteinosis. Respir Med. 2007;101(4):715-21.

22. Ashitani J, Mukae H, Hiratsuka T, Nakazato M, Kumamoto K, Matsukura S. Elevated levels of alpha-defensins in plasma and BAL fluid of patients with active pulmonary tuberculosis. Chest. 2002;121(2):519-26.

23. Ashitani J, Mukae H, Arimura $Y$, Sano A, Tokojima M, Nakazato M. High concentrations of alpha-defensins in plasma and bronchoalveolar lavage fluid of patients with acute respiratory distress syndrome. Life Sci. 2004;75(9):1123-34.

24. Ashitani J, Mukae $\mathrm{H}$, Nakazato $\mathrm{M}$, Ihi T, Mashimoto $\mathrm{H}$, Kadota JE, et al. Elevated concentrations of defensins in bronchoalveolar lavage fluid in diffuse panbronchiolitis. Eur Respir J. 1998;11(1):104-11.

25. Albrethsen J, Bogebo R, Gammeltoft S, Olsen J, Winther B, Raskov H. Upregulated expression of human neutrophil peptides 1,2 and 3 (HNP 1-3) in colon cancer serum and tumours: A biomarker study. BMC Cancer. 2005;19:5-8.

26. Albrethsen J, Moller $\mathrm{CH}$, Olsen J, Raskov H, Gammeltoft S. Human neutrophil peptides 1,2 and 3 are biochemical markers for metastatic colorectal cancer. Eur J Cancer. 2006;42(17):3057-64.

27. Kanmura $\mathrm{S}$, Uto $\mathrm{H}$, Numata $\mathrm{M}$, Hashimoto $\mathrm{S}$, Moriuchi $\mathrm{A}$, Fujita $\mathrm{H}$, et al. Human neutrophil peptides 1-3 are useful biomarkers in patients with active ulcerative colitis. Inflamm Bowel Dis. 2009;15(6):909-17.

28. Melle C, Ernst G, Schimmel B, Bleul A, Thieme H, Kaufmann R, et al. Discovery and identification of alpha-defensins as low abundant, tumor-derived serum markers in colorectal cancer. Gastroenterology. 2005;129(1):66-73.

29. Mohri Y, Mohri T, Wei W, Qi YJ, Martin A, Miki C, et al. Identification of macrophage migration inhibitory factor and human neutrophil peptides 1-3 as potential biomarkers for gastric cancer. Br J Cancer. 2009;101(2):295-302.

30. Mothes H, Melle C, Ernst G, Kaufmann R, Von EF, Settmacher U. Human Neutrophil Peptides 1-3-early markers in development of colorectal adenomas and carcinomas. Dis Markers. 2008;25(2):123-9.

31. Yamaguchi $\mathrm{N}$, Isomoto $\mathrm{H}$, Mukae $\mathrm{H}$, Ishimoto $\mathrm{H}$, Ohnita $\mathrm{K}$, Shikuwa $\mathrm{S}$, et al. Concentrations of alpha- and beta-defensins in plasma of patients with inflammatory bowel disease. Inflamm Res. 2009;58(4):192-7.

32. Muller CA, Markovic-Lipkovski J, Klatt T, Gamper J, Schwarz G, Beck H, et al. Human $\alpha$-defensins HNPs-1, -2 and -3 in renal cell carcinoma. Am J Pathol. 2002;160(4):1311-24.

33. Vlahou A, Schellhammer PF, Mendrinos S, Patel K, Kondylis FI, Gong L, et al. Development of a novel proteomic approach for the detection of transitional cell carcinoma of the bladder in urine. Am J Pathol. 2001;158(4):1491-502.

34. Mizukawa N, Sugiyama K, Fukunaga J, Ueno T, Mishima K, Takagi S, et al. Defensin-1, a peptide detected in the saliva of oral squamous cell carcinoma patients. Anticancer Res. 1998;18(6B):4645-9.

35. Mizukawa N, Sugiyama K, Ueno T, Mishima K, Takagi S, Sugahara T. Levels of human defensin-1, an antimicrobial peptide, in saliva of patients with oral inflammation. Oral Surg Oral Med Oral Pathol Oral Radiol Endod. 1999;87(5):539-43.

36. Mizukawa N, Sugiyama K, Ueno T, Mishima K, Takagi S, Sugahara T. Defensin-1, an antimicrobial peptide present in the saliva of patients with oral diseases. Oral Dis. 1999;5(2):139-42.

37. Goebel C, Mackay LG, Vickers ER, Mather LE. Determination of defensin HNP-1, HNP-2 and HNP-3 in human saliva by using LC/MS. Peptides. 2000;21(6):757-65.

38. ICH Q2B. International Conference on Harmonisation, Validation of Analytical Procedures. Methodology. 2005. 


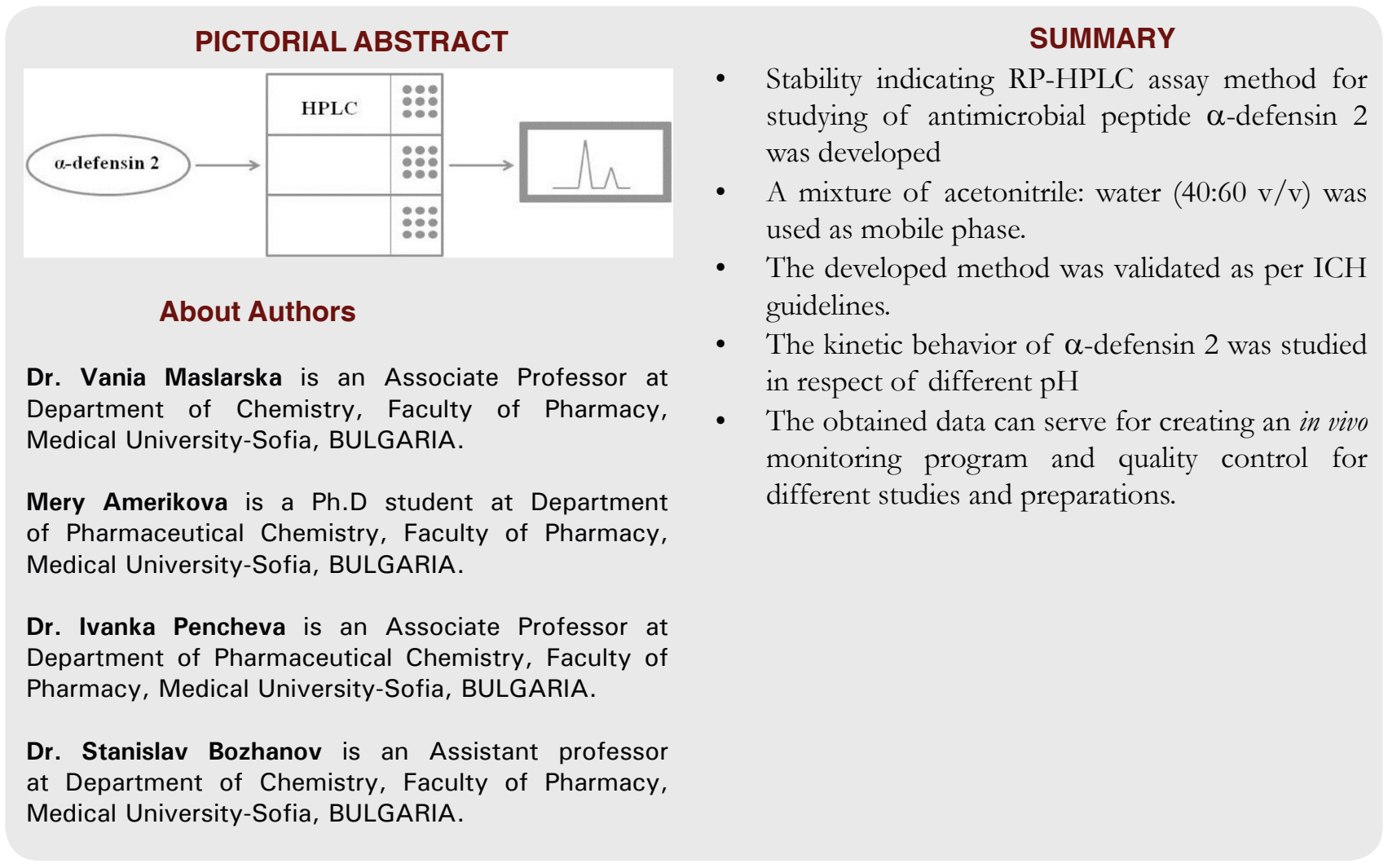

Cite this article: Maslarska V, Amerikova M, Pencheva I, Bozhanov S. HPLC Method for Determination of the Chemical Stability of Antimicrobial Peptide $\alpha$-Defensin 2. Indian J of Pharmaceutical Education and Research. 2020;54(2):465-70. 